Wind Energy Program Technology Portfolio

\title{
Low Wind Speed Technology Phase II: Development of a 2-MW Direct-Drive Wind Turbine for Low Wind Speed Sites
}

\section{Northern Power Systems}

Project Description: Previous design studies conducted by the U.S. Department of Energy (DOE) subcontractors have indicated that several new design configurations for wind energy technologies could offer significant opportunities for reducing the cost of energy (COE). These technology improvement opportunities include: reduction in the cost of and improvements in the efficiency of the drivetrain; increases in energy capture by increasing rotor diameter; and improved active wind turbine controls. The studies indicated that using several techniques can achieve these results. Many of these techniques are interrelated. For example, decreasing drivetrain weight can make the use of taller towers more cost effective, or introducing advanced rotor designs that decrease loads will allow greater rotor diameter, and hence, increased energy capture.

Consistent with this strategy, a team led by Northern Power Systems (NPS) has undertaken an effort to design, build, erect, and test a 2-MW wind turbine that integrates several technologies developed during earlier phases of the Low Wind Speed Technologies (LWST) project. The effort will utilize a high-energy-density, permanent-magnet, direct-drive generator based on

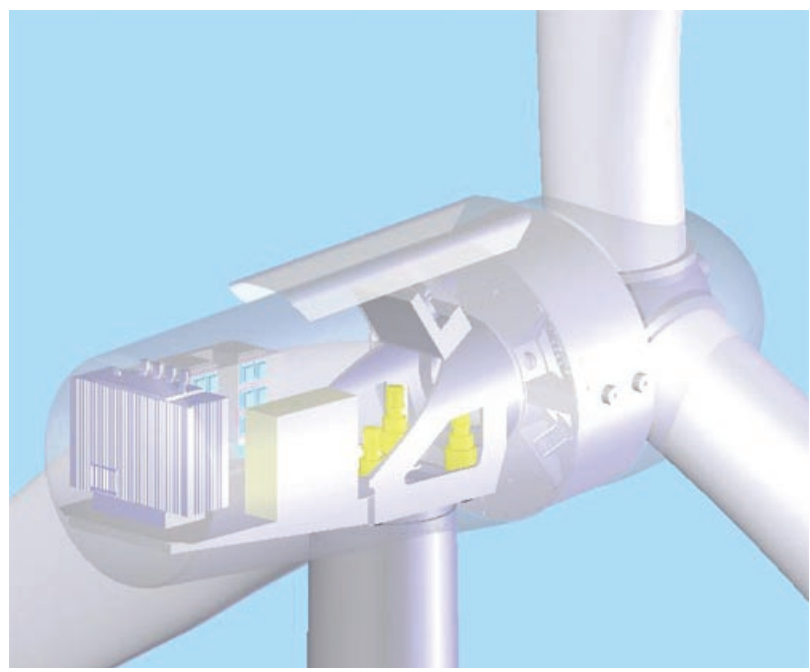

Concept illustration of the NPS 2-MW direct-drive wind turbine. work completed under the precursor WindPACT Program. In addition, the prototype will include an advanced power converter having insolated gate bipolar transitor (IGBT) active rectifier and line-side inverter stages that were developed and optimized under an LWST Phase 1 subcontract. Exploitation of these and other advanced technologies will increase energy capture, reduce erection and maintenance costs, capture other cost of energy advantages, and ultimately, generate electricity on a significantly more cost-effective basis than turbines using current technologies. The effectiveness of this design philosophy will be demonstrated in the final year of the subcontract, when a 2.2-MW prototype turbine will be tested at a low wind speed site in the United States.

\section{Project Type: \\ Total Project: \\ Prototype Development \\ Industry Cost Share: \\ $\$ 8,296,062$ \\ DOE Cost Share: \\ $\$ 2,654,011$ \\ $\$ 5,642,051$ \\ Planned Project Duration: July 2005-June 2008}

\section{Contacts:}

\section{NREL/Sandia:}

Scott Schreck, NREL

1617 Cole Blvd.

Golden, Colorado 80401

303-384-7102

scott_schreck@nrel.gov

Current Status:

\author{
Northern Power Systems: \\ Peter Mattila, NPS \\ 182 Mad River Park \\ Waitsfield, Vermont 05673 \\ 802-496-2955
}

Pmattila@northernpower.com

Project Underway

\begin{abstract}
A Strong Portfolio for a Strong America • Energy efficiency and clean, renewable energy will mean a stronger economy, a cleaner environment, and greater energy independence for America. Working with a wide array of state, community, industry, and university partners, the U.S. Department of Energy's Office of Energy Efficiency and Renewable Energy invests in a diverse portfolio of energy technologies.
\end{abstract}

For more information contact EERE Information Center • 1-877-EERE-INF (1-877-337-3463) • www.eere.energy.gov 